\title{
Cestovní ruch v protektorátní legislativě
}

\section{Jan Štemberk}

Vysoká škola obchodni v Praze

Kontaktni e-mail: stemberk@vso-praha.eu

\section{Tourism in the Protectorate Legislation}

\begin{abstract}
:
Pursued in this article is the development of tourism legislation during World War II respectively during the period of the Protectorate of Bohemia and Moravia. Making laws about tourism is described and evaluated in this text. The approval of laws was easier after the elimination of democratic institutions. Furthermore, the article studies the effect of German law-making on Protectorate legislation about tourism. Not only are the Protectorate regulations mentioned, but also rules stated directly by the German authorities. A complex overview of the legislation is not the aim of this study, but it follows the trends formed on individual levels of state policy, services, and activities connected with tourism.
\end{abstract}

\section{Keywords:}

tourism; Protectorate of Bohemia and Moravia; Nazi Germany; accommodation and catering; transport

\section{Klíčová slova:}

cestovní ruch; Protektorát Čechy a Morava; nacistické Německo; ubytovací a stravovací služby; doprava

DOI: $10.14712 / 2464689 X .2018 .23$

Financování: Příspěvek vznikl v rámci projektu GAČR č. 16-07164S „Pod dohledem Třetí říše. Cestovní ruch v letech 1939 až 1945“. 
Cestovní ruch představuje významné odvětví služeb, jehož vznik souvisí s přechodem od tradiční společnosti ke společnosti moderní, který byl zahájen na počátku 19. století. Oblast cestovního ruchu je z pohledu práva souborem řady dílčích úprav spadajících do oblasti veřejného i soukromého práva. Součástí práva, které reguluje oblast cestovního ruchu, je úprava provozu základních služeb poskytovaných turistům (ubytovací, stravovací, dopravní), dále služeb doplňkových (poskytování informací, apod.). Do oblasti cestovního ruchu výrazně zasahuje regulace pohybu a pobytu osob, zvláště otázka pasových, vízových a devizových předpisů. Opomenout nelze ani rovinu vztahu turisty (konzumenta) k poskytovatelům služeb, stejně jako otázku státní politiky cestovního ruchu, propagace cestovního ruchu a jejího financování. Pokud je cestovní ruch vnímán jako volnočasová aktivita, tak je potřebné sledovat i proměny fondu volného času (volné dny a dovolené).

V meziválečném období prošel cestovní ruch významným rozvojovým obdobím, které bychom mohli označit etapou demokratizace, nástupu nových dopravních prostředků, ale současně dobou zavádění devizových a dalších administrativních omezení mezinárodních cest. Charakteristickým je v této souvislosti i významný rozvoj domácího cestovního ruchu. ${ }^{1} \mathrm{Z}$ právněhistorického pohledu je období meziválečného Československa na legislativu spadající do oblasti cestovního ruchu poněkud skoupé. Na jedné straně po dobu deseti let probíhala prŕprava zákona o cestovním ruchu, který měl řešit kompetenční a finanční otázky. Žádná z připravených osnov však nebyla přijata. ${ }^{2} \mathrm{~V}$ obdobném duchu probíhaly legislativní práce na zákonu o cestovních kancelářích, který měl nahradit předlitavské ministerské nařízení č. 181/1895 ř. z. Jen ve formě diskusí zůstávala oblast standardizace ubytovacích služeb. Na druhé straně je možné poukázat zvláště na legislativu v oblasti cestovních pasů (zákon č. 55/1928 Sb. z. a n., o cestovních pasech), která liberalizovala podmínky získání cestovního dokladu. ${ }^{3}$ Od poloviny 30 . let stojí za zmínku i předpisy přinášející usnadnění v oblasti mezinárodní autoturistiky (např. vyhláška č. 50/1936 Sb. z. a n., vyhláška č. 73/1937 Sb. z. a n.).

Ačkoli by se mohlo na první pohled jevit, že doba faktické existence protektorátu Čechy a Morava stejně jako paralelně probíhající druhá světová válka nebyla obdobím, které by bylo v jakékoli formě nakloněno řešení jednotlivých problémů, do kterých se cestovní ruch dostával, tak opak je pravdou. V období do roku 1941 se setkáváme s koncepčními a kategorizačními opatřeními. Zbývající část války je spíše ve znamení snahy cestování omezit, $\mathrm{i}$ přesto se $\mathrm{v}$ této souvislosti setkáváme $\mathrm{s}$ legislativními zásahy, zvláště do oblasti fondu volného času, limitace délky pobytu v určitých lokalitách a omezení přístupu k veřejné i soukromé dopravě.

Předložený text si klade za cíl zmapovat a zhodnotit legislativní počiny na poli cestovního ruchu, jejichž přijímání se po odstranění demokratických institucí stávalo snadnějším. Dále si klade za cíl sledování vlivu německého zákonodárství na oblast protektorátní právní úpravy otázek cestovního ruchu. Předmětem pozornosti nejsou pouze protektorátní

1 Srovnej: ŠTEMBERK, J. Fenomén cestovního ruchu. Možnosti a limity cestovního ruchu v meziválečném Československu. Pelhřimov - Praha: Nová tiskárna ve spolupráci s Vysokou školou obchodní v Praze, 2009.

2 Srovnej: ŠTEMBERK, J. Meziválečné návrhy právní úpravy cestovního ruchu a současnost. Acta Universitatis Carolinae Iuridica, 2016, roč. 62, č. 3, s. 147-156.

3 Srovnej: RYCHLÍK, J. Cestování do ciziny v Habsburské monarchii a v Československu. Praha: Ústav pro soudobé dějiny AV ČR, 2007. 
předpisy, ale i pravidla stanovená přímo německou správou. Spíše okrajově budou sledovány prováděcí právní předpisy (např. vyhlášky Nejvyššího úřadu cenového) ${ }^{4}$ a mnohé faktické pokyny okupačních orgánů. Cílem není sestavit komplexní přehled legislativy, ale spíše sledování trendů, které se v jednotlivých rovinách státní politiky, služeb a aktivit spojených s cestovním ruchem profilovaly. Hlavní pozornost autora se zaměří na protektorátní i říšské sbírky právních předpisů, které budou doplněny jejich praktickými dopady zmapovanými na základě archivního studia. Právě části o jednotlivých službách a osobních předpokladech pro účast na cestovním ruchu poslouží pro zvýšení přehlednosti a členění celého textu.

\section{Organizace cestovního ruchu}

Již od konce 20. let probíhala jednání o potřebě komplexní organizace na poli cestovního ruchu, která by se stala nositelem celostátní i místní politiky cestovního ruchu. Připravené zákonné návrhy však nepostoupily ani do parlamentního projednávání. Plně se tak promítaly rozdílné pohledy na povahu organizace, její pravomoci, či vztah ke státu. ${ }^{5}$

Změněné podmínky spojené s přestavbou hospodářského života probíhající v prvních letech protektorátu vyvolávaly tlak na vytvoření centrálních organizací v jednotlivých hospodářských odvětvích. Stranou tohoto snažení nezůstal ani cestovní ruch. Zanedbatelnou nebyla ani potřeba centrálního ovládání podniků participujících na cestovním ruchu. Tento proces šel ruku v ruce s obecným trendem vytváření specializovaných hospodářských svazů s povinným členstvím. Předpokladem k budování nové organizace hospodářského života se stalo vládní nařízení č. 168/1939 Sb. z. a n. ze dne 23. června 1939. Ministr průmyslu, obchodu a živností byl zmocněn uznávat hospodářské svazy za výlučné zástupce svého hospodářského odvětví, zrrizovat nebo slučovat hospodářské svazy, a také stanovit povinné členství pro podniky, které měl svaz zastupovat. Cílem svazů mělo být hájení hospodářských zájmů členů, vedle toho však tvořily mezičlánek mezi centrálními orgány hospodářské politiky a jednotlivými podnikateli, aby se usnadnila komunikace a samozrejmě řízení hospodářského života a současně plnění ukládaných povinností.

Z Úřadu říšského protektora byla patrná snaha prosadit, aby oblast cestovního ruchu byla hospodářsky organizována obdobně jako v Říši, kde „organická“ výstavba německé ekonomiky probíhala již od roku 1934. Uznání svébytnosti cestovního ruchu však přicházelo s jistým opožděním. Teprve v listopadu 1938 byly jako odborná skupina v rámci ř́išské skupiny obchod (Reichsgruppe Handel) uznány lázeňské provozy (Fachgruppe Badebetriebe). Skupina zahrnovala podnikatele a podniky provozující živnostensky lázeňský provoz včetně státních a komunálních podniků. Součástí této odborné skupiny se však nestala říční a přímořská letoviska. ${ }^{6}$ Jednalo se jen o přechodné opatření, nebot' bylo zřejmé, že v rámci hospodářské skupiny obchodu se jedná o poněkud cizorodý prvek. Samostatná (sedmá) ř́šská (hospodářská) skupina cizinecký ruch (Reichsgruppe Fremdenverkehr) byla

\footnotetext{
4 K Nejvyššímu úřadu cenovému srovnej: JAKUBEC, I. - ŠTEMBERK, J. Die Oberste Preisbehörde - ein Regulator für Tourismusdienstleistungen (1939-1949). Prager wirtschafts- und sozialhistorische Mitteilungen / Prague Economic and Social History Papers, 2016, Vol. 24, s. 7-22.

5 Podrobněji viz ŠTEMBERK, Meziválečné návrhy právni úpravy cestovního ruchu a současnost.

6 Bundesarchiv Berlín (dále jen BA Berlín), Reichswirtschaftsministerium (dále jen RWM) R 3101/9291, Bd. 2, časopis Das Bad, 1938, Jhrg. 33, Nr. 10.
} 
zřízena následně v souladu s Pátým nařízením o organické výstavbě ze dne 4. dubna 1939. ${ }^{7}$ Tvořily ji hospodářská skupina hotelnictví (hostinské živnosti) a ubytovatelství (ubytovací živnosti) (Wirtschaftsgruppe Gaststätten und Beherbergungsgewerbe) a odborná skupina lázeňské provozy (Fachgruppe Badebetriebe). ${ }^{8} \mathrm{O}$ prrípadném začlenění dalších služeb cestovního ruchu zvláště cestovních kanceláří nebylo rozhodnuto. V čele hospodářské skupiny cizinecký ruch stál státní tajemník ministerstva národní osvěty a propagandy dr. Hermann Esser, ${ }^{9}$ do jehož kompetence cestovní ruch, jako jeden z nástrojů propagandy spadal.

Nařízením protektorátního ministra průmyslu, obchodu a živností z 9. září 1940 č. 386 Sb. z. a n. byl vytvořen Ústřední svaz pro cizinecký ruch v Čechách a na Moravě (dále též ÚSCR). ÚSCR vycházel z německé praxe jednotné centrální organizace pro cestovní ruch, ale jeho organizace se poněkud odlišovala. ${ }^{10}$ Podle svých stanov měl ÚSCR hájit hospodářské zájmy svých členů, poskytovat dobrozdání v otázkách souvisejících s cestovním ruchem a podávat návrhy na úpravy a zlepšení v oboru. Dále podporoval vydávání odborných a propagačních publikací. ${ }^{11}$ Je zřetelné, že cílem ÚSCR neměla být vlastní propagace cestovního ruchu. Český název svazu totiž zcela nekoresponduje s oficiálně používaným německým ekvivalentem Zentralverband der Fremdenverkehrswirtschaft, což jen dokládá, že v rámci činnosti ÚSCR sehrávaly hlavní úlohu hospodářské otázky. ÚSCR se jako hospodářská organizace dostal do působnosti ministerstva hospodářství.

Př́íprava vzniku centrální organizace, která „má nahradit všechny dosavadní organisace“ probíhala již od jara 1940.12 Střetávalo se několik koncepcí budoucího postavení a vztahu k řŕšské organizaci. Členství v Ústředním svazu pro cizinecký ruch bylo povinné pro všechny podniky, které provozovaly činnost hostinskou a hotelovou nebo živnostenský pronájem pokojů. Obdobně byly členy provozovatelé lázní (přírodních léčivých i parních a vanových) a veřejnosti přístupných sportovišt'. ${ }^{13}$ Svaz se dělil na dvě samostatné hospodářské skupiny - skupinu hostinských živností a skupinu lázní a sportovních míst. V době založení svazu se řešila otázka o začlenění cestovních kanceláří a minerálních zřídel. Ústřední svaz požadoval, aby byly zařazeny do jeho působnosti. Cestovní kanceláře měly podle názoru předsednictva svazu tvořit samostatnou - třetí hospodářskou skupinu. Podařilo se však dosáhnout jen částečného úspěchu, do hospodářské skupiny lázní a sportovních míst byla zařazena minerální zrrídla (byla vyčleněna z Ústředního svazu průmyslu).

7 Fünfte Verordnung zur Durchführung des organischen Aufbaues der deutschen Wirtschaft vom 4. 4. 1939 (RGB1. 1939, I, s. 734) podle zákona z 27. 2. 1934, RGB1. I., 1934, s. 185.

$8 \quad$ BA Berlín, RWM R 3101/9288 Bd. 1, čj. III W.O. 28557/39.

9 SLÁDEK, B. Organisace cizineckého a lázeňského ruchu v Říši. Národní politika, 1939, č. 155, 2. 6. 1939, S. 8 .

10 KOSE, J. Hospodářský význam cestovního ruchu. Sbirka přednášek České národohospodářské společnosti. Roč. 1940-1941, č. 9. Praha, 1940, s. 31; K situaci na Slovensku viz: PITEKOVÁ, J. Cestovný ruch na Slovensku počas II. svetovej vojny a v prvých rokoch po jej skončení. Ekonomická revue, 2006, roč. 9, č. 1, s. 52-58; SABOL, M. Dopravný systém Slovenskej republiky 1939-1941. In: MIČKO, P. - HALLON, L. a kol. Lesk a tiene hospodářského rozvoja Slovenska v rokoch 1939-1941. Krakov: Spolok Slovákov v Pol'sku, 2015; SABOL, M. Dejiny dopravy na Slovensku 1938-1948 (1950). Bratislava: Veda, 2015.

11 Národní archiv (dále jen NA), fond Ústřední svaz pro cizinecký ruch, k. 1, Stanovy ÚSCR v Čechách a na Moravě.

12 NA, fond Hospodářská skupina hostinských živností, kn. 2, Zápis ze schůze předsednictva Zemské jednoty společenstev hostinských z 14. 6. 1940.

13 KOSE, c. d., s. 31-32. 
Cestovní kanceláře byly i přes odpor svazu začleněny do Ústředního svazu dopravy, do hospodářské skupiny pomocných dopravních živností. ${ }^{14}$ Obecně můžeme sledovat v době existence protektorátu pokles významu cestovních kanceláŕí a omezování jejich činnosti.

Obě hospodářské skupiny měly celkem samostatné postavení a většinu svých činností vykonávaly samostatně. Vnitřně se mohly dále členit na odborné skupiny a ty potom na odbory. V čele každé hospodářské skupiny stáli předsedové jmenovaní ministrem. Ostatní orgány hospodářských skupin jmenoval Ústřední svaz. Hospodářská skupina hostinských živností se vnitřně dělila na odborné skupiny hostinskou (sdružovala odbory hostinců, velkorestaurací, zábavních podniků, kaváren, nádražních restaurací, vináren, výčepů lihovin a automatů) a hotelovou (sdružovala odbory hotelů $\mathrm{A}$ a $\mathrm{B}$, hotelů $\mathrm{C}$ a ubytovacích hostinců a lázeňských domů a penzionů).

Vládní nařízení č. 448/1941 Sb. z. a n. ze dne 17. prosince rušilo ke konci roku 1941 společenstva hostinských živností zakládaná podle živnostenského řádu, stejně jako okresní i zemské jednoty těchto společenstev vytvářené na základě vládního nařízení č. 302/1938 Sb. z. a n., doplňujícího živnostenský řád, s účinností od 1. ledna 1939. Působnost zrušených společenstev přecházela na ÚSCR a konkrétně na hospodářskou skupinu hostinských živností. Bývalá společenstva v sídelních městech jednotlivých politických okresů se stávala okresními hospodářskými skupinami. Ty z právního hlediska nepředstavovaly samostatné korporace jako zrušená společenstva, ale pouhé expozitury hospodářské skupiny hostinských živností. ${ }^{15}$

V roce 1942 byla provedena reforma územní působnosti hospodářské skupiny hostinských živností, kdy bylo prosazeno členění dle jednotlivých okresů. Na základě vyhlášky z 1. července 1942 č. 589 Ú. 1. byly jednotlivé místní úřadovny zrušeny a zachovány zůstaly jen ty v sídlech okresních úradů.

Úkolem Ústředního svazu pro cizinecký ruch bylo hospodářské řízení odvětví a samozřejmě vytváření předpokladů pro jeho další rozvoj. Hlavní náplní činnosti hospodářské skupiny bylo fungovat jako prostředník mezi státními orgány a jednotlivými podnikateli; zajišt'ovat provádění pokynů z centra a prosazovat jejich dodržování, tedy být převodní pákou při řízení ekonomiky. Působnost se prolínala jak na poli hospodářském zajištováním př́iělů surovin, udržováním dalšího provozu, distribucí pracovní síly, apod., tak i na poli administrativním evidencí podniků, zjišt'ováním kapacit pokojů a postelí, apod. Na jedné straně se hospodářská skupina včetně svých regionálních poboček snažila „mírniti tíhu různých nařízení“, která na hostinský stav doléhala, ale současně trvala na uposlechnutí „,veškerých výzev“ a správném plnění pokynů obsažených v oběžnících. ${ }^{16}$

Členství podniků v hospodářské skupině hostinských živností bylo celkem logicky odvoditelné a vztahovalo se na podniky mající oprávnění podle $§ 16$ živnostenského řádu. Poněkud komplikovanější bylo vymezení členství v hospodářské skupině lázní a sportovních míst. Vyhláška ministra průmyslu, obchodu a živností ze dne 29. dubna 1941 č. $184 \mathrm{Sb}$. z. a n. stanovovala povinné členství v hospodářské skupině lázní a sportovních

14 Blíže k Ústřednímu svazu dopravy viz ŠTEMBERK, J. Ústřední svaz dopravy 1940-1948. Acta Oeconomica Pragensia, 2007, roč. 15, č. 7, s. 406-417.

15 Státní okresní archiv Jindřichův Hradec (dále jen SOkA J. H.), fond Hospodářská skupina hostinských živností v Třeboni (dále jen HSHŽ Třeboň), kniha č. 2.

16 Archiv města Brna, fond Ústřední svaz pro cizinecký ruch - Hospodářská skupina hostinských živností, okresní skupina Brno-město, i. č. 3, Zpráva o činnosti v roce 1940. 
míst pro následující podniky a podnikatele: vlastníky a nájemce léčivých lázní a přírodních léčivých zdrojů; provozovatele parních a vanových lázní; podnikatele, kteří udržovali a pronajímali sportovní místa (sportovní haly, sportovní školy, kuželníky, stř̌elnice s pevným stanovištěm, kluziště s př́írodním i umělým ledem, sportovní hřiště, tenisová hřiště, půjčovny loděk, loděnice, sluneční lázně a lázně na stojaté i tekoucí vodě, plovárny všeho druhu a jiná tělovýchovná zařízení). V roce $1942^{17}$ byl okruh členů rozšíŕen o: provozovatele léčebných ústavů, včetně sanatorií a ozdravoven; provozovatele rekreačních a prázdninových zařízení a táborů, sloužících k zdravotní rekreaci a tělesnému otužení, a provozovatele zařízení pro cestovní ruch, jako rozhledny, jeskyně, panoramata, apod.

V Říši byl kromě uvedené povinné stavovské samostatné hospodářské organizace řŕšské skupiny cizinecký ruch ještě zřízen Říšský cizinecký svaz veřejnoprávní korporace říše (Reichsfremdenverkehrsverband öffentlich-rechtliche Körperschaft des Reiches). ${ }^{18}$ Zákon o říšském cizineckém svazu (Reichsfremdenverkehrsverband) z 26. března 1936 (RGBl. I, 1936, s. 271) s konečnou platností postavil tento svaz pod dohled speciálně vytvořeného oddělení cizineckého ruchu (Fremdenverkehr) v říšském ministerstvu pro lidovou osvětu a propagandu. Říšský cizinecký svaz sdružoval v roce 193824 zemských cizineckých svazů. Zemské cizinecké svazy seskupovaly místní cizinecké svazy letovisek (tzv. Fremdenverkehrsgemeinde). Těmi se stávala místa, ve kterých v době sezóny pobýval počet turistů, který překročil čtvrtinu trvalých obyvatel místa. ${ }^{19} \mathrm{~K}$ ř́išskému cizineckému svazu byla přidružena i Centrála říšských drah pro německý cestovní ruch (Reichsbahnzentrale für den Deutschen Reiseverkehr). Hlavním cílem Reichsbahnzentrale byla propagace, zejména $v$ zahraničí. Ta byla také podřizena Goebbelsově ministerstvu. ${ }^{20}$ V osobě Hermanna Essera se tak propojovala činnost obou organizací. Na oblast tzv. Sudet byla zcela rozšířena organizace cestovního ruchu platná ve „staré“ Říši. Výnosem rríšského komisaře pro Sudety ze dne 31. ř́ijna 1938 došlo k rozpuštění dosavadních cizineckých spolků (zemských /Karlovy Vary a Frývaldov/ i regionálních). Pro celou Sudetskou župu měl být vytvořen zemský cizinecký svaz. ${ }^{21}$ Dosavadní cizinecké spolky se mohly v dohodě s nově utvořeným svazem stát oblastními pobočkami. Ustavující valná hromada „Zemského cizineckého svazu pro Sudety“ (Landesfremdenverkehrsverband Sudetenland) se konala dne 17. ledna 1939 v Liberci. Do čela svazu byl jmenován Anton Kreissel. ${ }^{22} \mathrm{~S}$ účinností od 1. dubna 1939 byly v rámci Sudetské župy zakládány pobočky Hospodářské skupiny hotelnictví a ubytovatelství (Gaststätte- u. Beherbergungsgewerbe). ${ }^{23}$

Cizinecké svazy působily i na území protektorátu (v Praze a v Brně), jejich činnost však probíhala na spolkovém základě s dobrovolným členstvím a bez exekutivních funkcí.

17 Srovnej vyhlášku č. 357/1942 Sb. z. a n.

18 KOSE, c. d., s. 4.

19 FREI, P. Der Fremdenverkehr zwischen Deutschland und der Schweiz und seine Finanzierung unter der Devisenbewirtschaftung. München: Pilger-Druckerei, 1938, s. 16.

20 BERKTOLD-FACKLER, F. - KRUMBHOLZ, H. Reisen in Deutschland: Eine kleine Tourismusgeschichte. München - Wien: De Gruyter Oldenbourg, 1997, s. 73.

21 Státní okresní archiv Trutnov (dále jen SOkA Trutnov), fond Archiv města Vrchlabí, k. 189, i. č. 1874, Zuschrift vom 29. 11. 1938.

22 Státní okresní archiv Cheb, fond Landrát Aš, k. 562, i. č. 1080, sg. 705-00, Der Aufbau des Fremdenverkehrswesen im Sudetengau.

23 Tamtéž, k. 102, i. č. 234, sg. Pol.-Vb3. 
V roce 1944 sice byla připravována reorganizace náplně jejich činnosti inspirovaná ŕíšskou situací, tu se však s ohledem na další politický vývoj již nepodařilo uskutečnit.

\section{Ubytovací a stravovací služby}

Nutnost zajistit pro cestovní ruch určitý standard narůstala ve zvýšené míře po ztrátě turisticky atraktivních oblastí na podzim 1938. Cestovní ruch ve zmenšeném Československu bylo třeba nasměrovat do jiných míst, která k tomu však nebyla vybavena. Pro domácí i zahraniční turisty bylo třeba zajistit služby v odpovídající kvalitě. Je nutné poukázat, že většina turisticky atraktivních oblastí, které nabízely vyšší kvalitu služeb, se ocitla za novou hranicí. Tato východiska rozvádělo druhorepublikové vládní nařízení ze dne 17. února 1939 č. 23/1939 Sb. z. a n., o opatřeních v oboru hostinských a výčepních živností, zejména na podporu cestovního a sportovního ruchu. Nařízení, které platilo jen pro české země, zvyšovalo vliv státní správy na výkon živností, přičemž pověřovalo okresní úřady, aby dohlížely na kvalitu nabízených služeb. V př́ípadě potřeby byly okresní úřady oprávněny nařizovat provedení potřebných stavebních a dalších úprav a stanovit termín pro jejich provedení. Při nařizování těchto úprav úřady přihlížely $\mathrm{k}$ výnosovým poměrům podniku a majetkovým poměrům podnikatelů.

V oblasti čistoty bylo dbáno na prostory před podnikem i uvnitř podniku. „Podlaha ve výčepu i hostinských místnostech musí býti udržována v naprosté čistotě. Všechny závady, které brání péči o tuto čistotu dlužno odstraniti. Rovněž malba stěn, at' jde již o kteroukoli místnost hostům př́istupnou, musí býti udržována v dobrém stavu. Okna musí býti podle potřeby čištěna a usedlý prach častěji stírán. V hostinských místnostech musí býti postaráno o řádné větrání, aniž by tím vznikal škodlivý průvan. K tomu konci nutno poříditi přiměřený počet ventilačních zařizení (sklápěcí okna, ventilační roury apod.) [...] Přístup k záchodům, který musí býti v každém př́ípadě krytý, sluší označiti a řádně osvětliti. Ve všech podnicích, kde se převážně počítá s návštěvou nikoli místní, dlužno trvati na splachovacím zařízení. V předsíňce záchodové prostory nebo poblíž ní musí býti umístěno umyvadlo s mýdlem a ručníkem, který se podle potřeby musí vyměňovati. Pokud jde o koncesi s oprávněním podle bodu a/ $\$ 16$ ž. ř., [ubytovací zařízení; pozn. J. Š.] budiž postaráno o klosetní papír. U ostatních živností hostinských a výčepnických budiž opatření takového papíru doporučováno.“24

Obdobně jako čistota hostinských místností bylo sledováno i vybavení hostinských pokojů. Již ve 30 . letech často kritizované nedostatky byly v rámci provádění tohoto vládního nařízení shrnuty následujícím způsobem: „Hostinské pokoje musí míti řádně přiléhající dveře i okna. V postelích musí býti trojdílné žíněnky nebo matrace, položené na pružnou drátěnou vložku, nikoli snad jen slamníky. Mezi drátěnou vložkou a žíněnkou (matrací) se doporučuje umístiti ochrannou vložku. Ložní prádlo dlužno po každém hostovi bezpodmínečně vyměniti a upotřebené vyprati, nikoli jen mandlovati. Žíněnky nebo matrace dlužno po každém noclehu provzdušniti. Kromě lůžka musí býti v každém hostinském pokoji noční stolek s prríslušenstvím, skřiň nebo věšák na šaty, stůl s odpovídajícím počtem židlí, láhev s pitnou vodou, odlivka a sklenka na čištění zubů, není-li tekoucí vody se zapuštěným umyvadlem, též umývací stůl s dostatečně velkou mycí soupravou (zejména

24 SOkA J. H., fond HSHŽ Třeboň, k. 3, Nařízení o opatřeních v oboru hostinských a výčepnických živností provádění z 19. května 1939. 
nádoba na vodu o obsahu nejméně 4 litry a vědro pro vodu upotřebenou). Před lůžkem musí býti položen koberec, případně předložka. Zrcadlo budiž umístěno tak, aby ukazovalo alespoň osvětlený obličej. V každém pokoji, je-li zavedeno elektrické osvětlení, musí býti kromě stropního tělesa též stolní lampa na nočním stolku, jinak svíčka se zápalkami. Tam, kde není postaráno o elektrické vedení k nočnímu stolku, musí takový přívod býti opatřen při nejbližší malbě pokoje. V místnostech, které se pronajímají i mimo letní měsíce, musí býti postaráno o řádný otop. Každý pokoj musí býti opatřen signalisací, která ústí do místnosti zodpovědné osoby.“25 Okresní úřady získaly i pravomoc „předepsati rozvod teplé a studené vody, případně ústředního topeni'“, muselo se však jednat o místa, kde bylo možné očekávat zvýšený rozvoj cestovního ruchu. ${ }^{26}$ Kromě jiného měly úřady sledovat čistotu, jakost pokrmů a kvalitu obsluhy. Pokud by nařízené úpravy nebyly v termínu provedeny, hrozila podnikateli nejen pokuta, ale i ztráta koncesní listiny. ${ }^{27}$

Zvýšená pozornost českým ubytovacím zařízením byla věnována i krátce po vzniku protektorátu. Nedlouho po okupaci českých zemí byla provedena již řadu let diskutovaná kategorizace hotelů. Je zřejmé, že se jednalo o opatření, které mělo protektorátní podniky roztřídit podle kritérií a zajistit německému turistovi očekávanou kvalitu služeb. Je nutné poukázat, že předpis identického znění byl prosazen ještě dříve než v protektorátu na Slovensku (zákon č. 96/1939 Sl. z.). Vládní nařízení z 13. července 1939 č. 194/1939 Sb. z. a n., o třídění podniků hostinských živností s oprávněním k ubytování cizinců, rozdělilo ubytovací zařízení do čtyř kategorií $\mathrm{A}-\mathrm{D}(\mathrm{D}=$ ubytovací hostinec) s podrobným výčtem povinných znaků pro jednotlivé kategorie.

V nejvyšší kategorii A musely hotely splňovat 16 podmínek. Byly to podniky nejkomfortněji vybavené, které musely mít vzhledné průčelí, prostorný vchod, osvětlený nápis čitelný i za tmy, zvláštní místnosti pro přijímání hostů, recepci s nepřetržitou službou, nejméně dvě patra, výtah, jeden společenský salon, jídelnu pro podávání snídaně pouze pro hotelové hosty, podmínky pro vytvoření appartementů (salon, ložnice, koupelna), vybavení ústředním topením, elektrickým osvětlením, tekoucí studenou a teplou vodou, nehlučnou signalizací a předsíňkou nebo dvojitými dveřmi. Alespoň třetina pokojů musela mít vlastní koupelny a telefonní přístroj. Jedna společná koupelna mohla připadat maximálně na 10 pokojů. Předepsaný minimální počet pokojů se řídil velikostí místa - ve městech od 50 tisíc obyvatel to bylo 25 pokojů, u měst přes 100 tisíc obyvatel (např. v Praze) to bylo více než 40 pokojů. Pouze hotely této skupiny mohly používat označení Palace, Royal, Majestic apod.

Podmínky skupiny B splňovaly podniky poněkud menší, které však musely též vykazovat určitý komfort. Společná koupelna vystačovala na každých 10 pokojů, výtah byl předepsán jen pro budovy s více než třemi patry, podnik musel mít nejméně 10 pokojů a být vybaven ústředním topením. Hotel musel mít k dispozici oddělenou denní místnost.

Pro skupinu C byla žádána společná koupelna, splachovací toalety, minimálně pět pokojů a lakované podlahy, které mohly být již z měkkého dřeva. Poslední skupinu D představovaly tzv. ubytovací hostince, které označení hotel používat nesměly. O zařazení do určité skupiny musel podnik požádat příslušný okresní (koncesní) úřad. ${ }^{28}$ Touto kla-

Tamtéž.

Tamtéž.

NA, fond Ministerstvo vnitra-stará registratura, k. 4376, sg. 1/45/2.

Sbírka zákonů a nařízení Protektorátu Čechy a Morava 1939, Praha 1939, vládní nařízení č. 194. 
sifikací byl učiněn krok k zpřehlednění nabízených služeb. Návštěvník již předem věděl, jaký komfort může od navštíveného hotelu očekávat. Klasifikace také motivovala podniky k zlepšování nabízených služeb.

Protektorátní klasifikace ubytovacích zařízení přežila dobu existence protektorátu. Po únoru 1948 klasifikační pravidla posloužila při vymezení podniků pro probíhající znárodnění. Následně i v období socialismu zůstal systém písmen zachován a s ohledem na rozvoj typů ubytovacích zařízení byl spíše dále doplňován. Konec písmenům přivodil až nástup klasifikace v podobě hvězdiček.

Obdobně jako do oblasti ubytovacích zařízení zasáhla kategorizace i rovinu stravovacích služeb. Vyhláškou Nejvyššího cenového úřadu č. 279/1941 Ú. 1. ze dne 25. listopadu 1941 byla stravovací zařízení rozdělena do čtyř skupin. Toto rozdělení bylo provedeno z cenových důvodů a odráželo vybavení a provozní náklady podniku. Podle skupiny, do níž byl podnik zařazen, si mohl stanovovat ceny jídel, které byly cenovým úr̆adem limitovány. Na rozdíl od pozdějšího rozdělení známého z doby socialismu, bylo pořadí skupin převráceno. Do nejnižší první cenové skupiny spadaly jídelny, bufety a hostince, kde byla jídla podávána formou samoobsluhy. Druhá cenová skupina zahrnovala podniky, kde jídlo a pití roznášel obsluhující personál. Restaurace třetí cenové skupiny se nacházela obvykle ve velkých městech, lázních či letoviscích. Musela mít širokou nabídku pokrmů a personál musel ovládat alespoň jeden cizí jazyk. Restaurace čtvrté (nejvyšší) cenové skupiny již představovaly samotnou elitu restauračního podnikání. U obsluhy bylo požadováno, aby ovládala několik cizích jazyků a př́pravě jídla a pití musela být věnována zvláštní péče. $\mathrm{V}$ tomto případě se jednalo o podniky, které byly určeny převážně vyšším třídám a cizincům. ${ }^{29}$

Zprostředkovaně byla oblast stravovacích služeb zasažena i předpisy upravujícími přídělový systém v oblasti základních potravin. Na základě vyhlášky předsedy vlády č. 215/1939 Sb. z. a n. ze dne 29. záŕí 1939 byly zavedeny odběrní lístky na potraviny. Při objednávce ve stravovacím zařízení byl host povinen odevzdat patřičný ústřižek lístku podle použitého masa, tuku, mouky apod. Podrobnější pravidla pro osoby pravidelně cestující, prŕípadně osoby stravující se pravidelně v hostincích, i cizozemce, kteří zavítali do protektorátu, stanovila vyhláška předsedy vlády ze dne 15. prosince 1939 č. 307/1939 Sb. z. a n., kterou se upravuje stravování na cestách a v hostincích. Později byla změněna vyhláškami č. 246/1940 Sb. z. a n. ze dne 30. července 1940 a č. 208/1941 Sb. z. a n. ze dne 28. května 1941 vydanými na základě vládního nařízení č. 206/1939 Sb. z. a n., kterým bylo ministerstvo zemědělství zmocněno k opatřením v hospodaření s potravinami. Cestující, který se vydával na cestu delší než tři dny a v této době byl odkázán na stravování v hostincích, mohl požádat o vydání zvláštních potravinových lístků. Otázku vztahu mezi ř́šskoněmeckými a protektorátními potravinovými lístky při cestách a v hostincích řešila vyhláška předsedy vlády č. 121/1940 Sb. z. a n. ze dne 27. března 1940, o zastupitelnosti známek (lístků) pro cestující a hostince platných v Říši a v protektorátu. Říšské lístky platné pro cestující a hostince platily v protektorátu a naopak. Pravidla vzájemné zastupitelnosti potravinových lístků na cestách a v hostincích mezi Říší a protektorátem následně

29 BLAŽKA, M. Tvorba cen v hostinských a hotelových podnicích. Praha: Tiskařské družstvo v Praze, 1949, s. $13-14$. 
upravovala vyhláška ministra zemědělství ze dne 28. května 1941 č. 194/1941 Sb. z. a n., která zastupitelnost omezila jen na pohraniční pásmo (20 km od protektorátní hranice).

Stále se zpř́ísňující pravidla v oblasti hospodaření se základními potravinami se objevila ve vyhlášce ministra zemědělství ze dne 12. listopadu 1940 č. 399/1940 Sb. z. a n., o podávání pokrmů a polévek z poživatin v hostincích. Byl rozšiřren okruh pokrmů, které podléhaly při stravování $\mathrm{v}$ hostincích lístkové povinnosti. V jídelním lístku bylo vedle ceny nutné uvést i množství regulovaných potravin, které bylo použito na př́pravu pokrmu a tedy i jaký potravinový lístek bude požadován. Pro př́pravu jednoho jídla mohlo být použito maximálně $100 \mathrm{~g}$ masa. Za polévku mohly být lístky požadovány jen $\mathrm{v}$ tom př́ípadě, že byla podávána samostatně a ne jako součást menu. ${ }^{30}$

Zřetelná byla i snaha omezovat rozsah nabídky. Výnos ministerstva zemědělství z 8. dubna 1942 přikazoval hostinským zjednodušit jídelní lístek a omezit nabídku pokrmů. V pondělí a ve čtvrtek, pokud nebyl uznaný svátek, mohlo být podáváno jen jedno masité jídlo, s použitím maximálně $50 \mathrm{~g}$ masa, hostům mohlo být nabízeno pouze jedno menu, dále muselo být $\mathrm{v}$ tyto dny připraveno jednoduché jídlo $\mathrm{z}$,jednoho hrnce“.31 Jednalo se o obdobu německých „Eintopftage“, i název byl identický. S touto myšlenkou měl podle J. Goebbelse přijít Hermann Esser. Svou ideu na jeden až dva „Eintopftage“ v týdnu měl Esser předestř́t samotnému vůdci, který s jejich zavedením vyslovil souhlas. Je patrné, že komplikovanou situaci na poli zásobování základními potravinami si uvědomovala i nacistická politická elita. Sám Goebbels si ve svém deníku poznamenal, že „v př́štích letech budeme muset především zavést zásadní omezení v oblasti výživy“ ${ }^{32}$ Prvním bezmasým dnem se na základě nařízení č. 256/1939 Sb. z. a n. ve stravovacích podnicích stal pátek 10. listopadu 1939. Následně se tato situace měla opakovat v každý pátek. V tento den nesmělo být podáváno nejen maso, ale ani další pokrmy, ve kterých by bylo obsaženo. Pro potřeby tohoto nařízení nebyly za masité považovány pokrmy z ryb. ${ }^{33}$ Druhý bezmasý den (úterý) byl v protektorátu zaveden až v červnu 1941 (vyhláška ministra zemědělství č. 197/1941 Sb. z. a n. z 22. května 1941).

Cenová hladina stravovacích služeb byla v protektorátu obdobně jako v Říši limitována řadou vyhlášek Nejvyššího úřadu cenového. V praxi se tímto způsobem promítalo řízení cenové hladiny v protektorátu. Vyhláška ze dne 25. listopadu 1941, čj. 90.666-III/41941, o nejvyšších cenách jídel v živnostech hostinských, ${ }^{34}$ uváděla podrobný seznam jídel s maximální možnou cenou ve třech hostinských cenových skupinách. Nejlevnější polévka (hnědá nebo bílá) stála v rozmezí 1,50 až 2,30 K, nejdražší byl smažený telecí řízek nebo biftek (11 až $16 \mathrm{~K})$. Ceny pokrmů z drůbeže a zvěřiny stanovovala pro jednotlivé cenové skupiny vyhláška ze dne 18. února 1942, čj. 37.442-III/4-1942, o nejvyšších cenách pokrmů z drůbeže a zvěřiny v živnostech hostinských. ${ }^{35}$ Pro ilustraci pečená husa s obvyklou

30 SOkA J. H., fond HSHŽ Třeboň, k. 3, sg. I/2, Předpisy pro př́pravu a podávání pokrmů v hostinských živnostech.

31 Tamtéž.

32 „Wir werden überhaupt ins Laufe des nächsten Jahres erhebliche Einschränkungen in der Ernährungs durchführen müssen.“ Die Tagebücher von Joseph Goebbels, Teil 2, Band 2. München: Saur, 1996, Zápis z 11. 12. 1941, s. 476.

33 Státní okresní archiv Písek, fond Hospodářská skupina hostinských živností Písek, kn. 3, Zápis ze schůze z 10. 11. 1939 .

34 Úřední list, č. 279, 26. 11. 1941, s. 9790-9819.

35 Úřední list, č. 42, 19. 2. 1942, s. 1415-1417. 
př́lohou stála 18 až 27 K. Podle vyhlášky ze dne 13. dubna 1942, čj. 48.850-III/1-1942, o nejvyšších cenách jednoduchého jídla a jídel na $50 \mathrm{~g}$ ústřižky lístkủ na maso v hostinské činnosti, ${ }^{36}$ stála jednoduchá jídla podle kategorií 6,50 až $9 \mathrm{~K}$. Tytéž ceny platily např. pro hovězí vařené na lístky na 50 g. Vyhláška ze dne 15. května 1942, čj. 53.457-III/1-1942, o úpravě nejvyššího rozpětí při výčepu a prodeji vína v hostinské živnosti ve Velké Praze, ${ }^{37}$ umožňovala u I. cenové skupiny maximální přirážku k nabývací ceně 75 \%, u II. 120 \%, u III. 150 \% a u nejvyšší IV. $175 \%$. V př́loze byl uveden soupis provozoven v Praze podle čtvrtí a kategorií. Vyhláška ze dne 23. zář́i 1942, čj. 66.737-III/1-1942, o úpravě cen při výčepu a prodeji zdejšího i cizího vína v hostinské živnosti, ${ }^{38}$ stanovila, že v podnicích I. cenové skupiny nesměla hrubá zisková rozpětí $\mathrm{k}$ nákupní ceně překročit $70 \%(25 \mathrm{~K}$ za litr), II. 100 \% (30 K), III. $120 \%$ (40 K) a IV. $150 \%$ (75 K). Podle vyhlášky NúC ze dne 23. listopadu 1942, čj. 62.061-III/1-1942, o úpravě cen teplých nápojů v živnosti hostinské a výčepnické, ${ }^{39}$ stál malý šálek teplého nápoje (káva, čaj aj.) podle kategorie maximálně 1,30 až $2,20 \mathrm{~K}$, tzv. celá snídaně pak 6,50 až $9 \mathrm{~K}$.

Na první pohled by mohlo být překvapující, že $\mathrm{v}$ době druhé světové války se protektorátní i řrišská turistická letoviska potýkala s přeplněností, a to dokonce v takovém rozsahu, že muselo být přistupováno k omezování délky pobytu. Výnosem Říšského svazu cestovního ruchu (Reichsfremdenverkehrsverband) ze dne 26. června 1941 byl s ohledem na přeplněnost turistických letovisek omezen volný pobyt na 3 až 4 týdny v sezóně. Výnos platil jen pro oficiální turistická letoviska (Fremdenverkehrsgemeinde). Z tohoto omezení samozřejmě platily výjimky pro rekreující se př́slušníky ozbrojených sil, nemocné lázeňské hosty, matky s dětmi přesunuté na venkov z důvodu náletů, apod. Posilovala se i pozice správ letovisek při obsazování volných lůžek a jejich evidenci. ${ }^{40} \mathrm{~J}$. Goebbels ve svých záznamech odůvodňoval vydání výnosu potřebou zajistit př́islušníkům ozbrojených sil a německým pracujícím místa $\mathrm{k}$ zaslouženému odpočinku. ${ }^{41}$

Ve stejném duchu říšské inspirace bylo připraveno vládní nařízení č. 328/1943 Sb. z. a n., o ubytování $\mathrm{v}$ hotelích ze dne 31. prosince 1943. Základní limit pro pobyt $\mathrm{v}$ hotelích $\mathrm{v}$ téže obci činil sedm dní. $\mathrm{V}$ hotelích $\mathrm{v}$ lázeňských místech a $\mathrm{v}$ hotelích sloužících převážně k rekreačním pobytům se doba pobytu prodlužovala na 21 dní po sobě následujících. Ačkoli se tak na první pohled jednalo o přísnější omezení než v př́ípadě Říše, tak s ohledem na možnost opakujících se pobytů či přejezdů do jiných lokalit byl protektorátní předpis liberálnější. Žádosti o prodloužení limitu posuzovalo a povolovalo ministerstvo lidové osvěty.

Striktněji doléhala omezení v oblasti stravovacích a ubytovacích služeb na židovské obyvatelstvo. Kvůli těmto opatřením, se kterými se setkáváme od počátku existence protektorátu, se početnou a před válkou dobře finančně zajištěnou skupinu turistů podařilo z účasti na cestovním ruchu $\mathrm{v}$ zásadě vyloučit. Podle třetího nařízení k řrišskému občanskému zákoníku z 14. června 1938 musely být židovské podniky označeny. Nařízením z 26. dubna

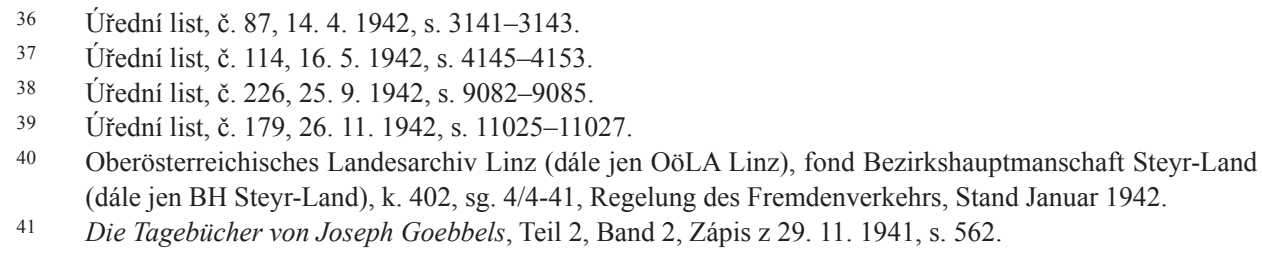


1939 byla platnost této povinnosti rozšířena i na Sudetskou župu. ${ }^{42} \mathrm{Na}$ území protektorátu se od konce léta 1939 objevovaly vyhlášky s regionální působností, které nařizovaly označování židovských provozoven a současně omezovaly vstup židovského obyvatelstva do kaváren, vináren, restaurací, lázní či plováren. Tyto vyhlášky byly vydávány na základě čl. 2 odst. 1 a čl. 3 odst. 1 zákona č. 125/1927 Sb. z. a n., o organizaci politické správy. Čl. 2 ukládal ministerstvu vnitra a politickým úřadům (napřr. okresní úřady) bdít nad veřejným „pořádkem, klidem, bezpečností a veřejnou mravností a odvraceti v tomto směru všeliká nebezpečenství i odstraňovati nastalé poruchy“. Navazující čl. 3 stanovil, že ke splnění účelu uvedeného v čl. 2 je možné vydávat obecně závazné příkazy a zákazy, včetně sankce za jejich porušení. Vydávání protižidovských opatření tak bylo odůvodňováno nutností zajistit veřejný pořádek, klid a bezpečnost. Bezpochyby se jednalo o extenzivní výklad shora uvedených ustanovení, který neodpovídal duchu celého předpisu. Ze strany okupačních orgánů bylo zřejmé, že obecně z psychologických důvodů preferují k potlačování práv a svobod využívání dřívějších „československých“ předpisů. ${ }^{43} \mathrm{Z}$ formulace čl. 3 bylo možné dovodit použití nejen k zákazům činnosti (návštěvy určitých míst), ale i k př́kazu určité činnosti (např. odevzdání řidičského průkazu, motorového vozidla apod.).

Jen pro ilustraci je možné uvést, že na základě rozhodnutí okresního úřadu v Uherském Brodě, landrátu ve Zlíně a luhačovické městské rady byl omezen pobyt židovských lázeňských hostů od července 1940 v Luhačovicích. Židovský host se musel vykázat lékařským potvrzením, které ještě podléhalo kontrole uvedené diagnózy. Pro Židy byly vyhrazeny podniky (Vila Marica, Vila Rusalka, Vila Adéla a hotel Miramar), jiné se pro ně staly nedostupnými. Jen v podnicích, kde byli ubytováni, se mohli stravovat. Kolonáda a parky byly pro židovské hosty uzavřeny. K léčivým pramenům měli přístup jen ráno do osmi hodin. ${ }^{44}$ Také argumentace vedoucí k zavedení opatření je ve své podstatě identická: zajistit bezpečnost v lázních a současně i uvolnit „,nejkrásnějšši“ místa, do té doby obsazovaná židovskými hosty, pro běžného občana (pracujícího), aby mohl odpočívat a čerpat nové síly v „„čistě árijském prostředí“ (,rein arischen Umgebung“) ${ }^{45}$

Na poněkud živelnou praxi reagoval výnos presidia ministerstva vnitra z 10. ř́ijna 1940 (č. E-3443-2/10-40) upravující pobyt Židů v lázních a letoviscích. Styk árijců a Židů v lázních, léčebných místech, letoviscích a zimních rekreačních místech měl být ,pokud možno co nejvíce omezen“. Okresní a policejní úřady byly ministerstvem vnitra vyzvány, aby vydaly podrobná regionálně platná pravidla $\mathrm{k}$ provedení tohoto výnosu. $Z$ neléčebných zařízení měli být Židé zcela vyloučeni. Pro Židy se zaváděla hlášení bez vyzvání v místě léčby. Obdobně měly být vydány okresními a policejními úřady vyhlášky pro letoviska a zimní rekreační místa. ${ }^{46}$

42 Archiv města Ústí n. L., fond Landrát Ústí n. L., k. 81, sg. Pol 501/4, Durchführund der dritte Verordnung zum Reichbürgergesetz, 26. 6. 1939.

43 NA, ÚŘP-ST, sg. 109-7/36 a 109-7/35, Arbeitsbericht des „Einsatzes TÜP“ Gruppe IV. des Komm. Leiters des Bodenamtes-Prag über die Zeit vom 1. August 1940 bis 1. Oktober 1941, s. 2.

44 Moravský zemský archiv Brno (dále jen MZA), fond Úřad ř́̌šského protektora, služebna pro zemi moravskou v Brně (dále jen ÚŘP Brno), k. 46, i. č. 523, Aufenthalt der Juden in Luhatschowitz - Einschränkung, 4. 7. 1940.

45 OöLA Linz, BH Grieskirchen, k. 404, sg. II/10-246/38.

46 NA, fond Ministerstvo průmyslu, obchodu a živností, k. 2751, čj. 83135, s. 1-4. 


\section{Doprava}

Oblast dopravy patřila k oborům, které byly novými opatřeními citelně zasaženy. Pro oblast cestovního ruchu ztratila své využití letecká doprava. Zásadní opatření se dotýkala silniční automobilové dopravy. Ve Věstníku nařízení Řišského protektora v Čechách a na Moravě vyšlo 18. září 1939 nařízení o dalším používání motorových vozidel v protektorátu. Ve své podstatě se jednalo o zákaz užívání vozidel pro volnočasové turistické jízdy.

Na silniční dopravu dolehla $\mathrm{v}$ březnu 1939 zásadní změna, která spočívala $\mathrm{v}$ přechodu na pravostranný provoz. Změna již byla v Československu připravena a měla nastat ke dni 1. května 1939 (srovnej opatření stálého výboru Národního shromáždění č. 275/1938 Sb. z. a n. z 10. listopadu 1938), nicméně březnové události tuto změnu urychlily, jak v českých zemích, kde došlo ke změně na základě nařízení velitele německé armády generála von Brauchitsche z 15. břrzna 1939 č. 5/1939 Věstníku říšského protektora, tak i na Slovensku, kde ke změně směru jízdy došlo od 18. března 1939 (vládní nařízení č. 13/1939 Sl. z.). V odstoupeném pohraničí byla změna směru jízdy provedena po obsazení na podzim 1938.

V záŕí 1939 došlo pod tlakem okupačních orgánů $\mathrm{k}$ urychlenému přijetí nových pravidel silničního provozu (nařízení č. 241-243/1939 Sb. z. a n.). Nové předpisy harmonizovaly protektorátní právo s říšskou úpravou a měly usnadnit jízdu německým řidičům. ${ }^{47}$ Je nutné poznamenat, že německá právní úprava pravidel silničního provozu byla hodnocena jako bezpečnější, než předchozí československá, to mělo za následek, že německé předpisy zůstávaly v českých zemích v platnosti i po osvobození. ${ }^{48}$

Také v oblasti železniční dopravy se projevovala nová opatření. Podle výnosu ze dne 28. března 1939 byl povolen volný prodej železničních jízdenek jen po území protektorátu a do sousedních států (Německo, Polsko a Slovensko). Jízdenky do ostatních zemí mohly být získány jen na zvláštní povolení. ${ }^{49}$ Počáteční období po vytvoření protektorátu bylo ještě spojeno se zlepšováním vzájemného železničního spojení. V létě roku 1939 byly zaváděny v relaci Praha - Říše nové rychlíky (č. 158/1939 Ú. 1. ze dne 15. července 1939). S ohledem na skutečnost, že železnice představovala státní podnik, měla většina prováděných opatření interní povahu.

V souvislosti s nárůstem dopravních výkonů pro válečné potřeby přicházela i další omezení při cestách železnicí. Ve své podstatě se limitace cestovního ruchu nejvíce rozbíhala $\mathrm{v}$ dopravě $\mathrm{v}$ souvislosti s omezenou kapacitou vlaků a nemožností vypravovat vlaky posilové. V Říši (samožrejmě včetně tzv. Sudet) se turisté poprvé s významnějším omezením volného cestování železnicí setkali v době svatodušních svátků na jaře 1940. Velikonoce 1940 byly spojeny jen se zákazem služebních cest a omezením možnosti čerpat dovolenou pro státní zaměstnance..$^{50}$ Oproti dosavadní obvyklé situaci v období významných svátků nebyly o svatodušních svátcích (10.-15. května 1940) vypravovány žádné posilové vlaky. Cestující tak museli vystačit s pravidelnými vlaky. Pro vlaky dálkové přepravy byly na období od 9. do 14. května 1940 zavedeny zvláštní „Zulassungkarten“, které bylo možné

\footnotetext{
47 Podrobněji srovnej: ŠTEMBERK, J. Automobilista v zajetí reality. Vývoj pravidel silničního provozu v českých zemich v prvni polovině 20. století. Praha: Karolinum, 2008, s. 118 a nás1.

48 Tamtéž, s. 134-135.

49 Úřední list č. 83 z roku 1939.

50 MZA, fond ÚŘP Brno, k. 9, i. č. 138, Urlaubreisen während des Osternverkehr, 7. 4. 1940.
} 
získat na nádražích. Předložení karty bylo předpokladem zakoupení jízdenky na dálkové vlaky, ale nezajišt’ovalo nárok na místo ve vlaku. ${ }^{51}$

Podstatné omezení osobní dopravy (vyjma cest do zaměstnání) přinesl podzim 1940. Již před létem 1940 byl vydán zákaz přepravy hromadných zájezdů, který se týkal i oficiálních akcí Radosti ze života, osvětové organizace Národního souručenství. Vyhláškou č. 607 ve Věstníku pro železnici a plavbu ze dne 4. řrijna 1940 byly s účinností od 12. ř́ijna 1940 „přechodně“ zrušeny na železnici turistické slevy. Slovo přechodně se však dá přeložit jako trvale, nebot' až do konce války obnoveny nebyly. Jedinou turistickou slevou, která zůstala zatím zachována, bylo poskytování 25 \% víkendové slevy pro obyvatele Prahy při cestách na vybraných tratích do vzdálenosti cca $30 \mathrm{~km}$ od města. Ani tato sleva však neměla dlouhého trvání a byla zrušena na jaře 1941.52 Nastupující snaha omezit cestování spojená se snížením počtu vlaků a jejich kapacity se logicky neslučovala s poskytováním turistických slev, nicméně odebrání turistických výhod nemělo za následek pokles cestujících.

Obdobně jako v Říši, bylo i v protektorátu vsazeno v první řadě na média, která měla nabádat $\mathrm{k}$ stř́izlivému využívání veřejné dopravy a jen $\mathrm{v}$ těch nejnutnějších případech. České Slovo apelovalo 29. března 1942 v článku „Úǔcelné a úsporné cestování železnicí“ s podtitulem „Přísné zachovávání dopravních předpisů a jen nutné jízdy jsou povinností občanstva!“ na minimalizaci jízd vlakem. Článek se odvolával na vyjádření ministra dopravy, ,aby železnice bylo používáno výhradně jenom k cestám nezbytným“. 53 Obdobně jako v Říši, tak i v protektorátu byly výzvy $\mathrm{k}$ omezení cestování velmi málo účinné. Na rozdíl od říšských drah však protektorátní dráhy dlouho nepřistoupily k zavedení zvláštních povolení „Zulassungkarten“ pro rychlíky a spěšné vlaky, zůstaly jen u výzev k omezení nedůležitých cest.

Při nákupu místenek do vlaků měly přednost osoby, jejichž cesty byly důležité pro válečné úsilí Říše. Cesty do lázní, rekreace a turistika byly výslovně označeny za nedůležité. Místenka pro turistické cesty mohla být prodána nejdř́ve tři dny před odjezdem, za předpokladu, že ve vlaku byla ještě volná místa. ${ }^{54}$

Na protektorátní občany dolehla omezení cestování železnicí o Velikonocích 1942. Nejprve následovaly výzvy k minimalizaci cest v období od 2. do 6. dubna 1942. Jasný pokyn směřoval správním úřadům, aby v zájmu ulehčení dopravě nepovolovaly žádné úřední cesty, až na nezbytné výjimky. Protektorátní úředníci byli též důrazně vyzváni, aby žádné cesty za účelem výletů nepodnikali. Výnos ministerstva dopravy a techniky z 26. března 1942 měl omezit cesty držitelů průkazů na slevu, když zakazoval jakékoli poskytování slev, zvláště železničářům a členům železničářských rodin. ${ }^{55} \mathrm{~V}$ obecné rovině však nebylo k žádným zvláštním pravidlům pro nákup jízdenek přistoupeno.

51 SOkA Trutnov, Trutnov, fond Archiv města Vrchlabí, k. 189, i. č. 1874, Rundschreiben 11/1940, 23. 4. 1940 .

52 Archiv tělesné výchovy a sportu Národního muzea, sbírka Turistika, k. 2, Kdy a kam 7, 1940, č. 4-5; Vyhláška ministerstva dopravy ze dne 1. října 1940 c), D $48803-I V / 31940$ uveřejněná ve Věstníku pro železnice a plavbu, II. věci přepravní a tarifní, č. 80a 40). Srovnej: Z úředních vyhlášek a nařízení, Český turista, 1940, 6, č. 10-11, s. 69.

53 České Slovo, 29. 3. 1942.

54 MZA, fond Zemský prezident - správa z př́kazu říše (dále jen ZP - správa z př́kazu říše), k. 86, Bericht vom 1. 7. 1942.

55 Státní okresní archiv Olomouc, fond Okresní úruad Olomouc-venkov - prezidiální spisy, k. 29. i. č. 1275, č. j. 268. 
Neobvyklý „dárek“ v podobě nařízení ministra dopravy a techniky ze dne 31. prosince 1942 o přepravě lyží veřejnými dopravními prostředky znamenal zákaz přepravy lyží. Nedodržování tohoto zákazu mohlo skončit vyloučením z přepravy a potrestáním. Pravděpodobně se jednalo o nezhoršování již tak přeplněných veřejných dopravních prostředků, ${ }^{56}$ ale současně mohlo souviset i se snahou omezit lyžování a neopotřebovávat stávající lyže, které se stávaly důležitým „prostředkem“ ve vedení války. V Říši byli vlastníci lyží vyzýváni, aby je odevzdali pro potřeby armády, a také v protektorátu byla vyhláškou ministra průmyslu, obchodu a živností č. 223 ze dne 29. října 1941 (čj. 118.263/41-I/E), o povinnosti nabídky a zákazu zcizení lyží, jejich př́slušenství a sněžnic, omezena dispozice. Vyhláška se vztahovala na lyže o délce $185 \mathrm{~cm}$ a delší. ${ }^{57}$

Také svatodušní svátky 1943 byly limitovány dopravními omezeními. V období od 12. do 15. června 1943 ministerstvo dopravy nařídilo, aby se jízdenky nevydávaly, když je vlak plně obsazen. Dále mohl být vyhláškou zastaven výdej vstupenek na nástupiště. Jízda musela být nastoupena v první den platnosti jízdenky, a to i na vzdálenost přes $100 \mathrm{~km}$. Rychlíky a spěšné vlaky nesměly být použity na vzdálenost do $75 \mathrm{~km}$. Dne 12 . června 1943 trval zákaz pro jízdu z Prahy rychlíkem a spěšným vlakem do Pardubic (všechny rychlíky), pro jízdu rychlíkem D 62 (Berlín - Vídeň /Linec/) z Prahy do Českých Budějovic a spěšnými vlaky č. 23 a 130 do Č́slavi a Př́brami. „Od cest pro zábavu nutno opustit. $\mathrm{K}$ jízdám za účelem návštěv jsou oprávněni jen ti, kdož z důvodů svého povolání musí žít odděleně od své rodiny. “58

Téměř zcela totožné omezení se dostavilo za necelý měsíc. Na počátku letních prázdnin 1943 vyšlo nařízení o regulaci železniční dopravy. Předně bylo „obecenstvo“ vyzváno, aby ,pokud možno nepodnikalo cest v prvních dnech prázdninových. To platí zejména pro ty, kdož nemají dítek školou povinných“. Ministerstvo dopravy nařídilo pro období 14. až 19. července 1943, aby se jízdenky nevydávaly, když je vlak plně obsazen. Dále se omezení týkala používání určitých rychlíků na kratší vzdálenosti. 59

Německý státní ministr pro Čechy a Moravu, v podstatě „viceprotektor“ K. H. Frank nařídil od 18. října 1943 zákaz používání spacích vozů 1. a 2. třídy pro cestující z osobních důvodů (dovolená, návštěva aj.). ${ }^{60}$ Ve své podstatě se jednalo jen o obdobu pravidla, které v Říši již platilo. Pro běžného cestujícího se staly dostupnými jen spací vozy III. tř́idy. Cestovní ruch omezovaly nejen úřední pokyny a nařízení, ale i železniční „,sabotáže““, 61 a později i nálety spojeneckých letců, tzv. kotlářů.

Vrchol představoval rok 1944, kdy byla dosavadní omezení zpř́ísňována. Jednoznačnou prioritou se stala přeprava zaměstnanců. V souvislosti s Velikonocemi 1944 vydal K. H. Frank výnos z 25. března 1944. Zabránit přeplněnosti vlaků měly povolenky

56 Úřední list, č. 1, 4. 1. 1943, s. 5, Nařízení ministra dopravy a techniky o přepravě lyží veřejnými dopravními prostředky.

57 Úřední list, č. 247, 31. 10. 1941, s. 8974-8978.

58 České Slovo, 11. 6. 1943; Národni Práce, 6. 6. 1943; Venkov, 6. 6. 1943.

59 Cestování o prázdninách. Národni Práce, 11. 7. 1943.

60 MZA, fond ZP - správa z př́kazu říše, k. 86, Az. VIII/1 b-10 V So-702/03, 14. 10. 1943.

61 Např. 8. srpna 1943 byl ochromen provoz Praha - Beroun, který se podařilo obnovit. Dne 1. záŕí 1943 byla eliminována trat’ Moravská Ostrava - Valašské Meziříčí. Poté následovala stagnace sabotáží do roku 1945 v Čechách a na Moravě do června 1944. BRANDES, D. Die Tschechen unter deutschem Protektorat. Teil II. München - Wien: Oldenbourg Wissenschaftsverlag, 1975, s. 92-93. 
(„,Zulassungskarten“). ${ }^{62}$ Podle Frankova názoru z 9. srpna 1944 měl být „silně zbytnělý cestovní ruch v co nejkratším čase“63 zásadně omezen. Předpokládalo se vydávání povolenek jen pro služební a obchodní cesty („Bescheinigung zur Benutzung der Eisenbahn“). Obdobně následoval další Frankův výnos z 3. listopadu 1944 ohledně prioritní dopravy pro vedení války. ${ }^{64}$

Nejvýraznější omezení osobní (civilní) dopravy přinesl počátek roku 1945. Podle výnosu oddělení III z 22. ledna 1945 čj. VII/1aV 720/44 směly od 23. ledna 1945 být služební cesty po železnici na více než $75 \mathrm{~km}$ uskutečněny jen s cestovním povolením (Reisegenehmigung) železničního ředitelství Praha (Hybernské nádraží). ${ }^{65}$ Německý státní ministr pro Čechy a Moravu vydal 22. ledna 1945 výnos o omezení v dopravě od 23. ledna 1945. Pro služební cesty a omezené obchodní cesty mající vazbu na vedení války povolení (od 26. ledna) vydávala železniční ředitelství a dopravní úřady, pro cestu služebními vlaky D-Züge jen železniční ředitelství Praha (Hybernské nádraží), a to po předložení platného osobního průkazu. ${ }^{66}$ Bez povolení byly možné cesty do vzdálenosti $75 \mathrm{~km}$ od místa bydliště nebo pracoviště a zpět, dále cesty na časové jízdenky také jen do $75 \mathrm{~km}$, a cesty př́islušníků wehrmachtu, diplomatů, a s platným pasem pro cesty do zahraničí a z něho. Sít’ové jízdenky a okresní jízdenky pozbývaly platnosti. ${ }^{67}$

Poslední válečná sezóna přinesla omezení soutěží a her, nebot’ byl vydán zákaz cestovat ke sportovním utkáním do vzdálenosti větší než 30 km. Od února 1945 se nesmělo vyjíždět vůbec. ${ }^{68} \mathrm{Na}$ jaře 1945 se železniční doprava v podstatě zhroutila vzhledem k blížící se frontě, hloubkovým náletům a sabotážím. ${ }^{69}$

Pomoci v odlehčení protektorátních železnic měla i tarifní reforma zavedená od května 1941. Tarif protektorátních drah měl být přizpůsoben výpočtu jízdného v Říši, to samozřejmě znamenalo jeho zvýšení. Tarif protektorátních drah byl zónový, s růstem slevy při větších vzdálenostech, naopak říšský tarif vycházel z ceny za ujetý kilometr, která byla odstupňována podle použité třídy vlaku. Př́íplatky za spěšné vlaky a rychlíky byly počítány dle ujetých kilometrů. Na krátké vzdálenosti došlo k růstu jízdného v průměru o $15 \%$ a na dlouhé dokonce v průměru o $30 \%{ }^{70}$ Růst cen jízdného pokračoval i nadále a celková cena jízdného vzrostla v průběhu okupace o cca $60 \%$.

62 MZA, fond ZP - správa z př́ikazu ř́̌še, k. 86, Az. PA 5010/44, Erlass vom 25. 3. 1944, Az. VIII/le lo V 71 $702 / \mathrm{ol}$.

63 „stark angeschwollenen Reiseverkehr in kürzester Frist“. MZA, fond ZP - správa z říšského př́ikazu, k. 86, Az. PA 5010/44.

64 MZA, fond ZP - správa z př́ikazu říše, k. 86, Az. VIII/1 b-10 V So-702/03, 14. 10. 1943, čj. PA-50/10/44, Erlass vom 3. 11. 1944 Aktz. VIII/B 3.312/44

65 NA, fond Německé státní ministerstvo pro Čechy a Moravu, k 107, i. č. 1348, online dostupné na: http:// www.badatelna.eu/fond/2199/reprodukce/?zaznamld=984032\&reprold=957730.

66 NA, fond Německé státní ministerstvo pro Čechy a Moravu, k 107, i. č. 1348, online dostupné na: http:// www.badatelna.eu/fond/2199/reprodukce/?zaznamld=984032\&reprold=957733, http:/www.badatelna.eu /fond/2199/reprodukce/?zaznamld=984032\&reprold=957734.

67 NA, fond Německé státní ministerstvo pro Čechy a Moravu, k 107, i. č. 1348, online dostupné na: http:// www.badatelna.eu/fond/2199/reprodukce/?zaznamld=984032\&reprold=957735, http:/www.badatelna.eu /fond/2199/reprodukce/?zaznamld=984032\&reprold=957736.

68 ŠŤASTNÝ, J. Železnice za protektorátu. Olomouc, 2008. Diplomová práce. FF UPOL, s. 183.

69 ŠŤASTNÝ, Železnice, s. 39.

70 MZA, fond ÚŘP Brno, k. 20, i. č. 238, Erhöhung der Fahrpreise auf den Protektoratsbahnen ab 1. 5. 1941, 29. 4. 1941. 


\section{Administrativní omezení pohybu}

Již po mnichovské dohodě se citelným způsobem zhoršila možnost zahraničního cestování československých občanů. Vládní nařízení č. 194/1938 Sb. z. a n. a č. 209/1938 Sb. z. a n. z 3. října 1938 omezovala cestování československých občanů do ciziny. Na konci roku sice byla oběma vládními nařízeními stanovená omezení zrušena (vládní nařízení č. 361/1938 Sb. z. a n. z 21. prosince 1938), avšak narůstaly překážky spojené s obnovováním vízové povinnosti. Dlouhodobé systematické práce na odstranění vízových překážek cestování po Evropě vzaly na podzim 1938 za své. Většina evropských států přistoupila $\mathrm{k}$ vypovídání dohod o bezvízovém styku. Československo na to reagovalo recipročními opatřeními. ${ }^{71} \mathrm{Je}$ až $\mathrm{s}$ podivem, jak evropské státy zachvátila obava $\mathrm{z}$ možného př́livu Čechoslováků z okleštěné republiky.

Vyhlášení protektorátu Čechy a Morava nezměnilo vzájemný cestovní styk a mezi protektorátem a Říši zůstala zachována hranice. Po zklidnění situace bezprostředně po okupaci bylo stanoveno, že pro překročení hranice mezi protektorátem a Říśí je nezbytná zvláštní propustka (vyhláška z 25. března 1939 č. 73/1939 Ú. 1.), kterou vystavuje velitelství státní tajné policie (Gestapa). Mezi Německem (včetně protektorátu) a mnohými evropskými státy (napřr. Slovenskem) zůstával zachován bezvízový styk (změna nastala po vypuknutí druhé světové války). Vedle cestovního pasu bylo na hranicích nadále požadováno předložení propustky (Durchlaßschein), kterou vydávaly německé okupační orgány. Stejná situace ale vládla i na hranici mezi Slovenskem a Říší. Obdobně byl Durchlaßschein vyžadován i pro cesty Slováků do Německa (včetně protektorátu). I na Slovensku byla propustka vydávána německými orgány. Dalo by se říci, že ačkoli neexistovala vízová povinnost, propustka plnila právě funkci víza. Pro vydání propustky musel žadatel oznámit důvod cesty, který byl následně zvážen, roli sehrávala i osobnost žadatele. $Z$ německé strany několikrát neoficiálně zaznělo, že propustka bude vydávána jen ve výjimečných př́ípadech..$^{72} \mathrm{Na}$ počátku léta 1939 bylo převedeno vydávání propustek z policejních složek na jednotlivé oberlandráty. Podle dobových zpráv to celé rízení urychlilo. Každý žadatel o propustku se musel na př́slušný oberlandrát dostavit osobně, bylo zakázáno, aby propustky zajištovaly cestovní kanceláře. O nové praxi vydávání propustek oberlandráty se dobové materiály ze srpna 1939 vyjadřují, že jsou nyní vydávány po doložení požadovaných dokumentů „blahovolně“. Sami Němci v srpnu 1939 naznačovali, že s postupným uklidňováním situace by i tato překážka mohla padnout. ${ }^{73}$ Připojení protektorátu ukazovalo novou německou taktiku v dostupnosti nově připojovaných území. Jak v př́ípadě území Rakouska, tak i českého pohraničí, byl po přechodné době zaveden volný cestovní styk. V průběhu druhé světové války se nově připojované oblasti nestávaly pro německého turistu volně př́stupnými a byla vyžadována nějaká obdoba propustky (Durchlaßschein).

Vypuknutí druhé světové války veškeré naděje na liberalizaci cestování do zahraničí zhatilo. Válka potíže naopak znásobila a vedla mimo jiné i k rozšiřování vízové povinnosti mezi Říši (včetně protektorátu) a evropskými státy. Pro občany protektorátu se možnost

\footnotetext{
71 Vyhlášky: č. 270/1938 Sb. z. a n. s Francií; č. 271/1938 Sb. z. a n. s Belgií; č. 272/1938 Sb. z. a n. se Švédskem; č. 351/1938 Sb. z. a n. s Jugoslávií; č. 13/1939 Sb. z. a n. s Norskem; č. 42/1939 Sb. z. a n. s Lotyšskem.

72 Slovenský národný archív (dále jen SNA), fond Ministerstvo hospodárstva (dále jen MH), k. 417, Spis č. III-437/39, Zpráva ze dne 22. 5. 1939.

73 SNA, fond MH, k. 418, Spis č. III-481/39, Dopis z 28. 8. 1939.
} 
vycestovat obecně zhoršila. Pro cestu do zahraničí bylo nutné získat nový cestovní pas, vízum a samozřejmě i propustku. Celý proces byl časově a finančně náročný a výsledek nejistý a neodhadnutelný. To samozřejmě snižovalo chut' takové martyrium podstoupit. ${ }^{74}$

Jistou formu administrativních omezení cestování měly i limity vývozu deviz, které byly na cestu do zahraničí přidělovány. Tento limit byl národní bankou využíván k limitaci výjezdového cestovního ruchu. V době německé okupace tento nástroj s ohledem na pravidla vydávání propustek a cestovních pasů poněkud ztratil na významu. Je však možné i zde pozorovat sbližování s říšskou praxí. Původní benevolentní přístup vybočující ze striktních pravidel středoevropských států byl zpř́ísňován. Do zahraničí bylo možné bez povolení vyvést pouze $100 \mathrm{~K}$ nebo $10 \mathrm{RM}$ (případně ekvivalent v cizí měně) za kalendářní měsíc. Vše, co přesahovalo, muselo být ze strany národní banky povoleno. Vyváženy však mohly být jen mince a bankovky do $20 \mathrm{~K}$, jejichž směna v zahraničí obvykle podléhala poplatkům. ${ }^{75}$

Generální omezení zahraničních cest mimo Říši znamenal oběžník říšského ministra hospodářství č. 34/42 z 12. května 1942. „Povolení pro civilní cestování do zahraničí zásadně se neudělují."76 Ze zákazu byly vyjmuty služební a obchodní cesty a cesty v naléhavém obecném zájmu, či pokud by neudělení vedlo k „neúnosné osobní tvrdosti“ (,zu einer untragbaren persönlichen Härte“), a na základě lékařského doporučení. Na Slovensko mohla být povolena cesta jen do lázní Piešt’any, Trenčianské Teplice, Vyšné Hágy, Nový Smokovec a Tatranská Kotlina. ${ }^{77}$

Je zřejmé, že okupační správa si nepřála cestování protektorátních občanů do zahraničí a ani ne do Ř́iše. Naopak protektorát se měl stát zázemím pro organizovanou rekreaci říšských př́slušníků, zvláště dětí. ${ }^{78}$

S radikálním návrhem na omezení volného cestování přišel Hermann Esser v létě 1943. Záměr pozastavit po dobu války veškerý cestovní ruch zaskočila i samotného Goebbelse, který s ohledem na zachování potřebné infrastruktury požadoval alespoň široce pojaté výjimky. ${ }^{79} \mathrm{~V}$ červenci 1943 vystoupil Hermann Esser v ř́šském rozhlase s výzvou proti přeplňování lázní a letovisek. Jeho projev však vyvolal spíše opačnou reakci a v samotných letoviscích zavládlo přesvědčení, že se připravuje spíše ulehčení cestovního ruchu než jeho omezování. Celý systém se dostával do patové situace. Na jedné straně převažovalo přesvědčení o nutnosti omezit cestovní ruch a na druhé chyběla rázná opatření. ${ }^{80}$

\footnotetext{
74 Podrobněji viz RYCHLÍK, $c . d$.

75 Srovnej např. vyhlášku ministerstva financí č. 327/1940 Sb.

76 „... sind die Genehmigungen für den Zivilre is ev erk ehr nach Ausland grundsätzlich nicht zu erteilen“. Runderlass des Reichswirtschaftsministers Nr. 34/42 vom 12. Mai 1942 Zivilreiseverkehr nach dem Ausland (ausgenommen Dienst- und Geschäftsreisen), Runderlasse des Reichswisrtschaftsministers, 13. Mai 1942, Sächsische Staatsarchiv Dresden, fond Hauptarchivstaatsarchiv Dresden, 11177 Oberfinanzpräsident Nr. 367; NA, fond Ministerstvo hospodářství a práce (dále jen MHP), k. 203, čj. 63 476/42.

77 Tamtéž.

78 K této problematice viz JAKUBEC, I. Die Bedeutung des Protektorats Böhmen und Mähren für das Reich aus der Sicht des Tourimus. West Bohemian Historical Review, 2017, roč. 7, č. 2, s. 293-330; ŠUSTROVÁ, R. Pod ochranou protektorátu: Kinderlandverschickung v Čechách a na Moravě: politika, každodennost a pamět' 1940-1945. Praha: FF UK, 2012.

79 Die Tagebücher von Joseph Goebbels, Teil 2, Band 9. Zápis ze 7. 8. 1943, s. 235.

80 SD-Berichte vom 29. 7. 1943, in: BOBERACH, H. (Hg.). Meldungen aus dem Reich. Bd. 14. Hersching: Pawlak, 1984, s. 5546.
} 
V průběhu sledovaného období docházelo k omezování či zakazování vstupu a pohybu v určitých oblastech. Jednalo se o oblasti vojenských prostorů (Brdy, Milovice, Vyškov), oblasti s vysídleným českým obyvatelstvem určené k vytváření německých ostrovů (Neveklovsko, Sedlčansko), stejně jako oblasti pohraničního pásma. Definitivní omezení cestovního ruchu přineslo nařízení říšského ministra dopravy o omezení cestování z 1. dubna 1945.81

\section{Volný čas a placená dovolená}

Výrazných změn nedoznal v prvních letech okupace fond volného času. Samozřejmě je nutné připomenout, že základní změnu přinášelo zavedení pracovní povinnosti nejprve pro mužskou část populace a později i pro ženy. Úprava dovolených na zotavenou byla v prvních letech okupace $\mathrm{v}$ zásadě ponechána na stejné úrovni jako v meziválečném Československu. Velkou pozornost věnovaly protektorátní úřady pracovním podmínkám včetně precizace nároku na dovolenou v jednotlivých odvětvích. Jen do konce roku 1939 bylo vydáno 5 takovýchto vyhlášek ministra sociální a zdravotní správy pro zemědělské, lesní dělníky, zaměstnance lékáren a průmyslu čokolády a cukrovinek. V následujícím roce to bylo již 32 vyhlášek. V roce 1941 pak 50, v roce 1942 ,jen“ 25, v roce 1943 devět, v roce 1944 pouze tři a v roce 1945 jen dvě.

Vládní nařízení č. 237/1940 Sb. z. a n. ze dne 22. února 1940 měnilo zákon ze dne 3. dubna 1925 č. $67 \mathrm{Sb}$. z. a n., kterým se zaváděla placená dovolená pro zaměstnance. Učňům do 16 let vznikl nárok na dovolenou na 14 dní, starším učňům na 12 dní. Další vládní nařízení č. 91/1941 Sb. z. a n. ze dne 19. prosince 1940, jímž se měnil zákon ze dne 1. července 1921 č. 262 Sb. z. a n., kterým se zavádí placená dovolená pro dělníky při dolování na vyhrazené nerosty, znamenala pro dělníky do 16 let po půlroční době nárok na 14 dní, od 16 do 18 let na 12 dní. Vládní nařízení č. 33/1942 Sb. z. a n. ze dne 18. prosince 1941, o placené dovolené pro zaměstnance, přiznalo horníkům nárok po minimálně 6 měsících na 6 dní, po minimálně 5 letech na 7 dní, minimálně po 10 letech na 10 dní. V prŕípadě práce přes 15 let činil dokonce nárok 12 dní. Pro ostatní v nepřetržitém provozu byl minimálně po 6 měsících nárok na 6 dní, po minimálně 10 letech na 7 dní a přes 15 let na 8 dní.

Nařízení říšského ministra vnitra ze dne 11. dubna 1942 se týkalo dovolené na zotavenou pro úředníky a zaměstnance veřejného sektoru pro rok 1942. Vzhledem k válečným poměrům nebylo povoleno více než 21 dní. Osoby narozené před 1. dubnem 1888 měly zaručeno maximálně 31 dní. ${ }^{82}$

V průběhu války se objevily také přesuny nároků na dovolenou do prř́štího roku. Vyhláška protektorátního ministra hospodářství a práce č. 150/1942 Sb. z. a n. ze dne 23. dubna 1942, kterou se provádí vládní nařízení ze dne 18. prosince 1941, č. 33 Sb. z. a n. z roku 1942, o placené dovolené pro zaměstnance, umožňovala převod, pokud válečný stav nedovolí vybrat si dovolenou v řádném termínu. Čerpání vyhláška umožňovala až do 30. června následujícího roku (§ 1 odst. 1), jinak mohla nevybraná dovolená být proplacena (§ 1 odst. 2$)$.

81 Verordnung zur Einschränkung des Reiseverkehrs. Vom 1. Februar 1945, RGB1. I, 1945, s. 21.

82 Anordnung über den Erholungsurlaub der Beamten und Angestellten im öffetlichen Dienst für das Urlaubsjahr 1942. Vom 11. April 1942, RGB1., Jg. 1942, I Teil, s. 168. 
V protektorátních úřadech byla délka dovolené upravována dílčími ministerskými výnosy, které pro daný rok určovaly maximální výměru dovolené. Hlavním pravidlem pro poskytování dovolené se stala zásada, že „Dovolená na zotavenou se poskytne, pokud to dovolí válečné poměry“. ${ }^{83}$ Nárok na dovolenou se měnil i v průběhu jednotlivých roků. Na jaře 1942 ministerstvo lidové osvěty svým zaměstnancům přislíbilo maximálně 21 dnů dovolené v roce. V záŕí téhož roku však byl nárok zkrácen na maximálně 14 dnů v roce. Postiženi tak byli ti zaměstnanci, kteří si dovolenou v delší výměře dosud nestihli vyčerpat, nebo ji právě čerpali, ti měli být ihned povoláni zpět do úřadů. ${ }^{84}$

Další z úprav dovolené na zotavenou byla vyhláška ministra hospodářství a práce ze dne 25. března 1944 o úpravě dovolené na zotavenou za rok 1944. ${ }^{85}$ Velké omezení čerpání dovolené na zotavenou znamenala vyhláška ministra hospodářství a práce ze dne 29. ř́ijna 1944 k provedení nařízení o prozatímním zastavení dovolených v soukromém hospodářství. Omezení se netýkalo léčebných pobytů schválených sociálním pojištěním, dále organizací zabývajících se organizováním dovolené v protektorátu, avšak pro pobyty nutné z lékařského hlediska: Reichserholungswerk der Deutschen Arbeitsfront, Sozialerholungswerk der Deutschen Rentenversicherung, zaopatřovací úřady Říše a protektorátu pro válečné poškozence a válečné pozůstalé, Jugenderholungswerk der Hitler-Jugend, Frauenamt der Deutschen Arbeitsfront a zotavovací akce pro mládež pořádané Kuratoriem pro výchovu mládeže v Čechách a na Moravě. ${ }^{86}$

Z nařízení ministra hospodářství a práce č. 182/1944 Sb. z. a n. ze dne 26. srpna 1944, o prozatímním zastavení dovolených v soukromém hospodářství, získali výjimku muži po dovršení 65 let, ženy po dovršení 50 let do 31. prosince 1944 a manželky př́islušníků branné moci. Zastavení dovolených se netýkalo poskytnutí volna v prrípadech úmrtí či životu nebezpečné nemoci manžela (manželky) a nejbližších příbuzných včetně porodu, zejm. se netýkalo těžkých poškozenců, žen a mladistvých na základě lékařského osvědčení, držitelů či nájemců zemědělských usedlostí k obdělání polí a sklizně a volna nastávajících a kojících matek $(\S 1)$.

Vládní nařízení č. 199/1944 Sb. z. a n. zavádělo pro muže starší 16 let šedesátihodinový pracovní týden. U žen byla týdenní pracovní doba stanovena na 56 hodin.

Volný čas byl spojen s víkendy (sobotním odpolednem a volnou nedělí) a svátky. $\mathrm{S}$ ohledem na politické změny se „státní“ svátky spojily se svátky církevními. Oslavy dnů upomínajících Československo nebyly žádoucí a nevznikly ani nové svátky spojené s připojením k Říši.

Až do roku 1942 se svátky a památné dny přesouvaly na konec týdne, většinou na neděli. Za svátky byly podle vládního nařízení č. 63/1939 Sb. z. a n. prohlášeny Nový rok, Sv. tří králů, pondělí velikonoční, Nanebevstoupení páně, pondělí svatodušní, Božího Těla, Sv. apoštolů Petra a Pavla, Nanebevzetí Panny Marie, Všech Svatých, Neposkvrněného Početí Panny Marie, Hod Boží vánoční a druhý svátek vánoční. ${ }^{87}$ De jure se jednalo o změnu zákona č. 65/1925 Sb. z. a n. ze dne 3. dubna 1925.

\footnotetext{
83 NA, fond Ministerstvo lidové osvěty - dodatky, k. 1, i. č. 1, Dovolená na zotavenou - doplněk, 16. 6. 1942.

84 Ibid., k. 1, i. č. 3, Schnellbrief vom 15. 9. 1942.

85 Úřední list, č. 74, 28. 3. 1944, s. 1401-1402.

86 Úřední list, č. 258, 1. 11. 1944, s. 507-5077.

87 Vládní nařízení č. 63/1939 Sb. z. a n. ze dne 9. března 1939.
} 
V ř́ššém zákoníku v dubnu 1939 publikovaný zákon o př́ležitostných zvláštních svátcích ze 17. dubna 1939 zmocňoval říšského ministra vnitra ve spolupráci s říšským ministrem práce a ř́ššsým ministrem hospodářství k vyhlašování všedních dnů či jejich částí na celém území Říše za svátky. ${ }^{88}$ Nařízením z dubna 1940 získal 1. květen charakter státního svátku v protektorátu tak jako v Ř́ísi. ${ }^{89}$

Vládní nařízení č. 200/1940 Sb. z. a n. ze dne 18. června 1940 se týkalo 29. června, 5. a 6. července. Den 29. červen 1940 nebyl pokládán za svátek a památné dny 5. a 6. červenec se „odkládaly“ podle dobové terminologie na neděli 7. července. Vládní nařízení č. 250/1940 Sb. z. a n. ze dne 6. srpna 1940 se týkalo jen 15. srpna 1940, který nebyl považován za svátek. Vládní nařízení č. 300/1940 Sb. ze dne 19. záŕí 1940 „odkládalo“ památný den 28. záŕí, stejně jako církevní slavnosti na neděli 29. září 1940. Vládní nařízení č. 385/1940 Sb. z. a n. ze dne 24. ř́ijna 1940 „odložilo“ svátek 1. listopadu stejně jako církevní slavnosti na neděli 3. listopadu. Vládní nařízení č. 440/1940 Sb. z. a n. ze dne 9. prosince 1940 o dočasné úpravě některých svátků zrušilo svátky po dobu války 6 . ledna, 29. června, 15. srpna, 1. listopadu a 8. prosince.

Rok 1941 přinesl další přesuny: svátky Nanebevstoupení a Božího Těla byly přesunuty na neděli. ${ }^{90}$ Vládní nařízení č. 253/1941 Sb. z. a n. ze dne 1. července 1941 „odkládalo“ 5. červenec stejně jako církevní slavnosti na neděli 6. července. Nařízení z října 1941 znamenalo trvalý přesun svátků Nanebevstoupení a Božího Těla na neděli a omezení církevních obřadů. ${ }^{91}$ Vládní nařízení č. 225/1942 Sb. z. a n. ze dne 12 . června 1942 už bylo vydáno jako závazné „,po dobu mimořádných hospodářských poměrů, způsobených válkou“. Dokonce podle $\S 1$ mohl zemský úřad bez ohledu na platné předpisy o nedělním klidu nařídit dočasnou odlišnou úpravu nedělního a svátečního klidu v podnicích ve svém okruhu.

Vládní nařízení č. 236/1942 Sb. z. a n. ze dne 1. července 1942 se týkalo přeložení církevních slavností památného 6. července na neděli 5. července. Vládní nařízení č. 336/1942 Sb. z. a n. ze dne 26. záŕí 1942 se týkalo celkové úpravy svátkového práva za války. V případě, že by připadly památné dny 28. září, 5. a 6. červenec na všední den, přeloží se stejně jako církevní slavnosti na následující neděli. ${ }^{92}$

Z uvedeného je zřejmé, že okruh volného času se v oblasti svátků omezoval. S narůstajícím válečným úsilím a neúspěchy na frontách byla potřeba zvýšeného pracovního úsilí, které se s volným časem neslučovalo. Jasně se ukazovala platnost hesla, které mělo odrazovat říšské občany od cestování „Zuerst siegen, dann reisen“.

\section{Závěr}

Oblast cestovního ruchu, tedy společenských aktivit spojených s volnočasovým cestováním představovala neodmyslitelnou součást protektorátní i říšské legislativy. Cestovní ruch a jeho demokratizace patřily k výkladním skř́ním národně socialistického režimu, proto mu byla věnována náležitá pozornost v rámci prezentace systému širším společenským

\footnotetext{
88 RGB1. I, 1939, s. 763; Verordnungsblatt des Reichsprotektors in Böhmen und Mähren, 1939, s. 59-60.

89 Verordnungblatt des Reichsprotektors in Böhmen und Mähren, 1940, s. 185.

90 Verordnungblatt des Reichsprotektors in Böhmen und Mähren, 1941, s. 263.

91 Verordnungblatt des Reichsprotektors in Böhmen und Mähren, 1941, s. 596.

92 K problematice svátků srv. nejnověji SLEZÁK, F. Svátky a manifestace v obdobi Protektorátu Čechy a Morava 1939-1945. Brno, 2012. Bakalářská práce. Masarykova univerzita, s. 17-18.
} 
vrstvám. Legislativa jde jednoznačně regulačním a kategorizačním směrem. Obdobně jako v celém hospodářství se ukazovala potřeba jednotlivé aktivity na základě společných kritérií roztřídit a následně stanovit pravidla a tyto i kontrolovat.

V obecném měřítku je nutné počítat se snahou Říše využívat území protektorátu i pro oblast rekreace. Nedošlo však cíleně k otevření hranice a nekontrolovanému př́livu osob, naopak byla zvolena koncepce řízených organizovaných návštěv (německé děti, vojsko, apod.). Prostor pro výjezdový cestovní ruch z protektorátu se neustále zhoršoval. Pravidla stanovovala okupační moc, která si samozřejmě nepřála Čechy cestující po nové Evropě. Pro českého turistu tak zůstávalo s drobnými výjimkami dostupné jen území protektorátu. Ačkoli se i zde setkával se stoupajícími omezeními (přídělový systém, omezování nabídky, omezování dopravy, apod.), rozhodně nelze zvláště pro první polovinu konfliktu (do druhé poloviny roku 1941) hovořit o cílených opatřeních k omezení cestování. Je poněkud paradoxní, že přísnější pravidla platila v samotné Říši, než v protektorátu. Na rozdíl od pasových záležitostí měl protektorát v oblasti železniční dopravy a ubytovacích služeb relativní autonomii, která se vyznačovala poněkud liberálnější politikou. Je však obtížné osvětlit, zda se jednalo o cílenou snahu poskytnout protektorátu v tomto směru určité výhody, nebo o nezájem Ř́iše tuto oblast přísněji regulovat. To však nijak nezmenšovalo aktivitu Říše k harmonizaci právní situace v protektorátu. Organizační struktura a systém řízení nemusely být totožné, ale měly umožnit obdobný způsob řízení celého odvětví.

V souladu se zaváděním řízeného hospodářství docházelo $\mathrm{k}$ regulačním zásahům, které představovaly nejpočetnější skupinu legislativy přijaté v rámci oblasti tzv. cestovního práva. Regulace postihovala stranu nabídky, povinné členství hostinských, provozovatelů volnočasových aktivit, cestovních kancelárí, apod. v státem řízených oborových organizacích, kategorizaci ubytovacích a stravovacích zařízení; dotýkala se však i spotřebitelů zvláště při eliminaci židovského obyvatelstva, a současně i při limitech délky pobytu v turistických letoviscích.

S ohledem na omezený rozsah a mnohovrstevnatost protektorátní i říšské legislativy cestovního ruchu nemohla být věnována pozornost všem souvislostem, je však zř̉ejmé, že oblast cestovního ruchu byla v obzoru zájmu protektorátní legislativy a byla ve složité válečné době řešena. Další odpovědi zajisté bude moci poskytnout pokračující právněhistorický výzkum dané tematiky. 